\title{
HENTRIACONTANE: A LEAF HYDROCARBON FROM Syzygium jambos WITH STIMULATORY EFFECTS ON THE GERMINATION OF UREDINIOSPORES OF Puccinia psidii
}

\author{
DAURI J. TESSMANN ${ }^{1} \&$ JOSÉ C. DIANESE ${ }^{2}$
}

${ }^{1}$ Departamento de Agronomia, Universidade Estadual de Maringá, Cx. Postal 331, CEP 89020-900, Maringá, PR, e-mail: djtessmann@uem.br; ${ }^{2}$ Departamento de Fitopatologia, Universidade de Brasília, CEP 87000-000, Brasília, DF

(Accepted for publication on 12/08/2002)

Corresponding author: Dauri J. Tessmann

TESSMANN, D.J. \& DIANESE, J.C. Hentriacontane: a leaf hydrocarbon from Syzygium jambos with stimulatory effects on the germination of urediniospores of Puccinia psidii. Fitopatologia Brasileira 27:538-542. 2002.

\begin{abstract}
A crude Sohxlet extract from leaves of Syzygium jambos was sequentially fractionated using a silica gel flash column. A bioassay based on the numbers of urediniospores of Puccinia psidii that germinated in $2 \%$ water agar detected an active stimulant of germination when the fraction eluted with $100 \% \mathrm{n}$-hexane was used. The active fraction induced up to $88 \%$ increase in germination when added to a spore suspension in mineral oil. The active fraction was characterized as a hydrocarbon by ${ }^{1} \mathrm{H}$ nuclear magnetic resonance, ${ }^{13} \mathrm{C}$ nuclear

magnetic resonance, and infrared analysis. Gas chromatography-mass spectrometry analysis indicated that the fraction was a long-chain $436 \mathrm{MW}$ hydrocarbon with corresponding to $\mathrm{C}_{31} \mathrm{H}_{64}$, namely hentriacontane. This is the first time such a compound proved to be involved with stimulation of fungal spore germination. These results may contribute to better understanding the infection process of rusts.

Additional key words: germination, Myrtaceae, rust, Urediniospores, fungal spore germination.
\end{abstract}

\section{Hentriacontano: um hidrocarboneto obtido de folhas de Syzygium jambos com efeito estimulante sobre a germinação de urediniósporos de Puccinia psidii}

Foi obtido um extrato orgânico de folhas de jambeiro (Syzygium jambos) com um extrator Sohxlet e as frações do extrato foram purificadas através de cromatografia de coluna. $\mathrm{O}$ efeito estimulante das frações sobre a germinação de urediniósporos de Puccinia psidii foi avaliado através de um bioensaio em água ágar $2 \%$. Uma fração eluida com n-hexano $100 \%$ teve atividade estimulante sobre a germinação que aumentou em até $88 \%$, comparado à testemunha com somente óleo mineral. Esta fração ativa foi caracterizada como um hidrocarboneto através de espectrometria de infra-vermelho e por ressonância nuclear magnética de prótons e de ${ }^{13} \mathrm{C}$. A análise de espectrometria de massa em cromatógrafo de gás indicou ser a substância estimulante um hidrocarboneto de cadeia longa e não ramificado, com peso molecular 436, correspondendo à fórmula $\mathrm{C}_{31} \mathrm{H}_{64}$, denominado hentriacontano. Esta foi a primeira constatação do efeito estimulante deste composto sobre a germinação de esporos de fungos. Estes resultados contribuem para o melhor entendimento do processo de infecção das ferrugens nas plantas hospedeiras.
Rust fungi are obligate plant parasite that form as many as five different types of spores during their complex life cycles. The urediniospore is the repeating stage in the cycle and its production underlies the exponential growth of the pathogen population (Scott \& Chakravorty, 1982; Lucas \& Knights, 1987). Urediniospores are dispersed by wind and germination on surface of plant hosts is a critical step towards infection and successful colonization. Indeed, interest in the germination of rust urediniospores has risen from the analysis of the factors controlling development of plant diseases with implications not only in the understanding of pathogen-host relations, but also in developing practical approaches to control epidemics in the field.

Puccinia psidii Winter causes severe rust epidemics in rose apple [Syzygium jambos (L.) Alston] and in several other Myrtaceae in South America, such as guava (Psidium guajava L.), and Eucalyptus spp. (Dianese et al., 1984; Ferreira, 1989; Mendes et al., 1998). Albeit urediniospores have an important role in the disease progress, however, the infection process of this rust and its regulation is poorly understood (Coutinho et al., 1998). Urediniospores of P. psidii do not germinate in vitro when suspended in water, which is evidence of the existence of some mechanism regulating spores germination. Such regulation, also observed in other rust fungi (Lucas \& Knight, 1987), is thought to be important for fungal survival. It prevents the germination of spore in situ, the germination of spores aggregates and also fast germination before dispersed spores can reach the infection site on the host (Griffin, 1994). Physical factors such as temperature, leaf wetness duration, and light intensity are known to affect spore germination. However, several substances can regulate urediniospores germination, including 
Hentriacontane: a leaf hydrocarbon from Syzygium jambos with stimulatory effects...

endogenous self-inhibitory chemicals and substances that stimulate germination (Lucas \& Knight, 1987; French, 1992; Griffin, 1994). The list of compounds which stimulate urediniospore germination include fatty alcohols, aldehydes, ketones, saturated and unsaturated linear hydrocarbons, isoprene derivatives, cyclic compounds, volatile esters, mercaptans, sulfides, thiocyanates, nitriles, amines, and amides. Also active were nonvolatile derivatives such as water-soluble 1,9-nonanediol, sodium octyl and nonyl sulfonates, and water-insoluble n-nonamide (French \& Gallimore, 1971; Charudattan et al., 1981; French, 1992). However, it is not known whether these compounds act directly on the same system and even less is known about the significance on uredioniospore germination of stimulants originating from the host plant itself. The present study was undertaken to provide more insights regarding the stimulatory effect of components of plant epicuticular wax on the germination of urediniospores of $P$. psidii.

Fresh urediniospores were produced on leaves of potted $S$. jambos plants in the greenhouse. Young plants were inoculated by spraying a $10^{4}$ urediniospores per $\mathrm{ml}$ water suspension, also containing 0.05\% Tween-20 (Sigma Chemical Co., St. Louis, MO, USA). After inoculation, the plants were placed in a dew chamber at $22{ }^{\circ} \mathrm{C}$ for $24 \mathrm{~h}$ in continuous dark and then transferred to a greenhouse. Urediniospores were collected 12 days after inoculation.

Germination tests were carried out in Petri dishes (10$\mathrm{cm}$ diam.) containing $2 \%$ water agar. Preliminary observations indicated that $P$. psdii urediniospores practically do not germinate in vitro when suspended in water. Thus, the spores were suspended in mineral oil (Nujol, Schering S.A., Rio de Janeiro, RJ, Brazil) at a concentration of $2 \times 10^{4}$ urediniospores per $\mathrm{ml}$. Fractions from column chromatography were added to the spore suspension at rates of $0,2,20,200,2000$, and $20000 \mathrm{ppm}$ in order to test their effect in germination. Each Petri dish received $0.5 \mathrm{ml}$ of the spore suspensions uniformly distributed on the medium with a glass rod. The urediniospores were incubated at $22{ }^{\circ} \mathrm{C}$ for $24 \mathrm{~h}$ in continuous dark. Four petri dishes were used per treatment. At the end of each incubation period, a drop of lactophenol cotton blue was deposited at the center of each dish to prevent further germination. A glass cover slip was then placed over the spot stained by the lactophenol cotton blue. Using a compound microscope (150x), germinated and non-germinated urediniospores were counted in each of ten randomly selected ocular fields $\left(1.91 \mathrm{~mm}^{2}\right)$ in each Petri dish. Urediniospores with germ tube length greater than or equal to the spore diameter were considered germinated. The analysis was based on the percentage of germinated spores present in each of the treatments: stimulatory compound or plant extract concentration.

A crude extract of epicuticular wax was obtained from intact young leaves of $S$. jambos using a 2-1 Sohxlet extractor, supplied with n-hexane for $5 \mathrm{~h}$. This extract was sequentially fractionated through column flash chromatography using 60mesh silica gel (Carlo Erba, Milano, Italy) and different concentrations of ethyl acetate in n-hexane. The purity of fractions was determined by thin layer chromatography, eluting with $25 \%$ ethyl acetate in n-hexane. Gas chromatography-mass spectrometric analysis of the purified active fraction was carried out on a Hewlett-Packard 5970 GC-MS (Hewlett Packard Co., Palo Alto, CA, USA). NMR analysis was performed on a Varian EM-390 spectrometer (Varian Instrument Division, Palo Alto, CA, USA) operating at $90 \mathrm{Mhz}$. The infrared spectrum was recorded in $\mathrm{KBr}$ using a Baush and Lomb Spectronic 2000 spectrophotometer (Baush \& Lomb Inc., Rochester, NY, USA).

Nine fractions were purified from the crude Sohxlet extract of epicuticular wax of $S$. jambos leaves, but only the fraction eluted in $100 \%$ n-hexane positively affected germination of $P$. psidii urediniospores when dissolved in mineral oil. Spores did not germinate when suspended only in water. The maximum germination stimulus ( $88 \%$ increase in germination in relation to pure mineral oil) was observed when spores were treated with $200 \mathrm{ppm}$ of the $100 \%$ n-hexane (Figure 1). The same concentration-dependent germination response was observed when the crude Sohxlet extract was added to mineral oil at concentrations ranging from 20 to $200 \mathrm{ppm}$.

The content of the active fraction was characterised as a hydrocarbon by ${ }^{1} \mathrm{H}$ nuclear magnetic resonance (NMR) (Figure 2), ${ }^{13} \mathrm{C}$ nuclear magnetic resonance (Figure 3 ), and infrared analysis (IR) (Figure 4). Gas chromatography-mass spectrometry (GC-MS) indicated that this fraction was an unbranched long chain hydrocarbon, with a $436 \mathrm{MW}$, corresponding to the structural formula $\mathrm{C}_{31} \mathrm{H}_{64}$ (hentriacontane) (Figure 5).

Hydrocarbons have been reported previously as a stimulant of urediniospore germination. French \& Gallimore

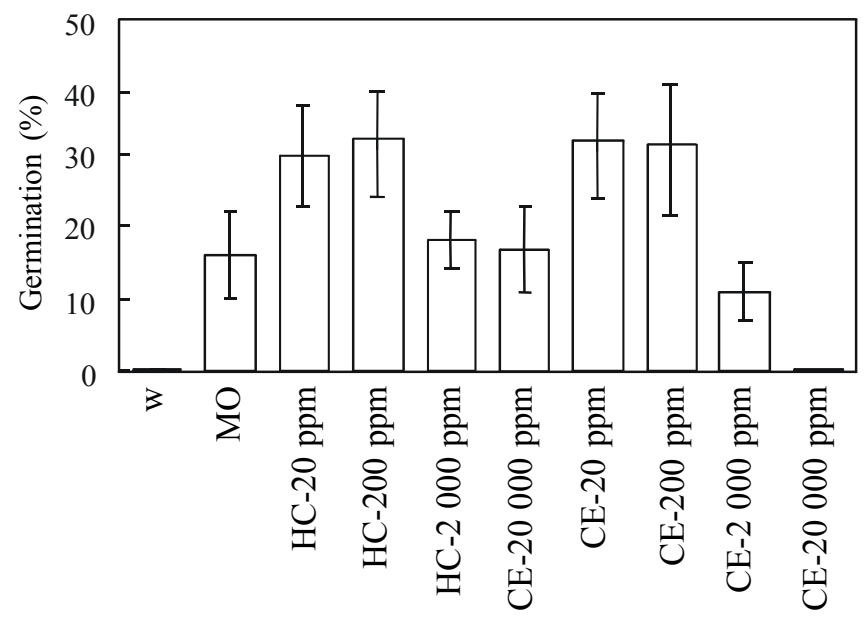

FIG. 1 - Germination of Puccinia psidii urediniospores on 2\% water agar in Petri dishes. Spores suspended in water (W), mineral oil (MO), and in mineral oil at several concentrations of hentriacontane (HC) or in crude Sohxlet extract of Syzygium jambos leaves (CE). Results are means \pm S.D. 


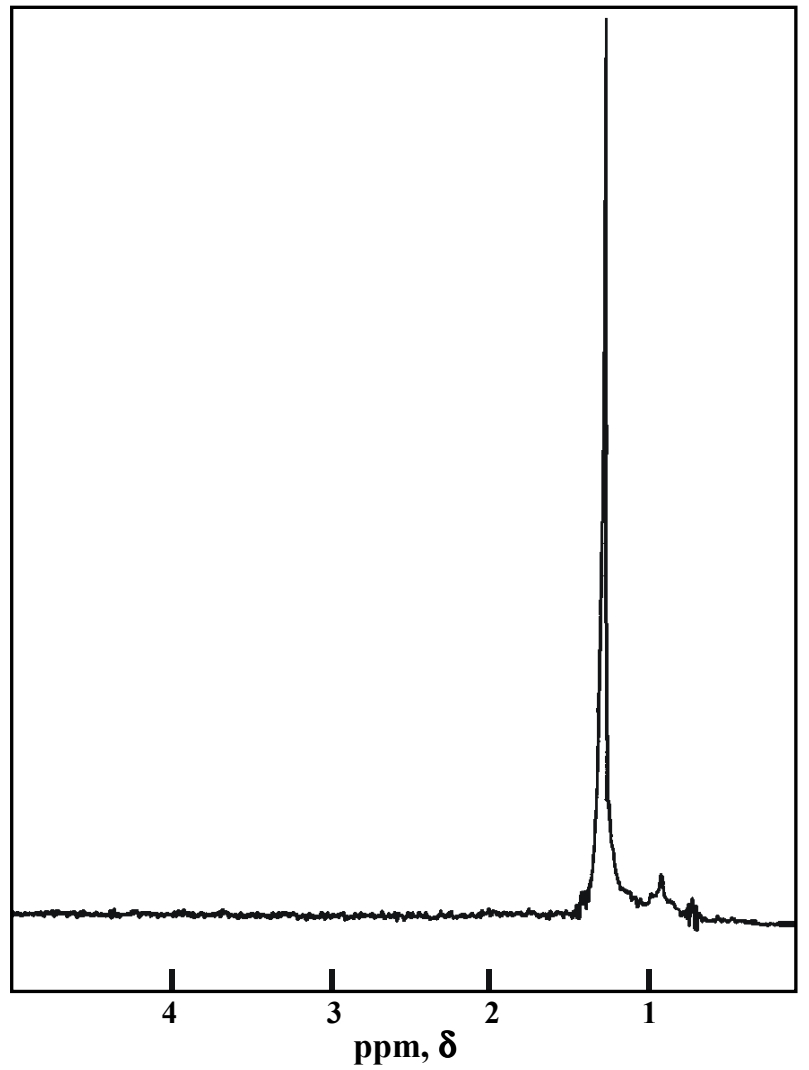

FIG. 2 - ${ }^{1} \mathrm{H}$ nuclear magnetic resonance spectrogram of the fraction purified from crude Sohxlet extract of Syzygium jambos leaves that actively stimulate germination of Puccinia psidii urediniospores.
(1971) reported a stimulatory effect of the n-nonano, 1noneno, and trans-2-noneno, on germination of Puccinia graminis Pers.:Pers. f.sp. tritici Eriks. \& E. Henn. urediniospores. However, in contrast to this study, those compounds were not extracted from the plant host but from synthetic chemicals.

The role of hydrocarbons in urediniospore germination still is not clear. The activity of a diverse group of chemicals on urediniospore germination suggests that stimulation of germination does not occur by reaction with one particular enzyme or by enhancement of the concentration of one specific metabolite (French \& Gallimore, 1971). Yet, urediniospores are comparatively large propagules containing reserves of lipid and carbohydrate and many studies have shown that these spores are not dependent on an exogenous supply of nutrients for germination (Lucas \& Knight, 1987). For instance, alkanes were shown not be an efficient source of energy for germination of urediniospores of $P$. griminis f.sp. tritici (Wilkinson \& Roberts, 1990).

The stimulatory effect of hentriacontane, as well as mineral oil, which is a mixture of hydrocarbons, on spore germination may result from a counteracting effect of such substances against self inhibitory compounds present in the spore. As shown in previous studies, germination of rust spores can be stimulated by counteracting the effects of selfinhibitors (Griffin, 1994). In addition, when urediniospores land on plants they first meet the surface wax; therefore, such chemicals could participate in the development of signals for the beginning of a plant-fungus interaction (Kolattukudy et al., 1995).

Even though the presence of the hydrocarbon

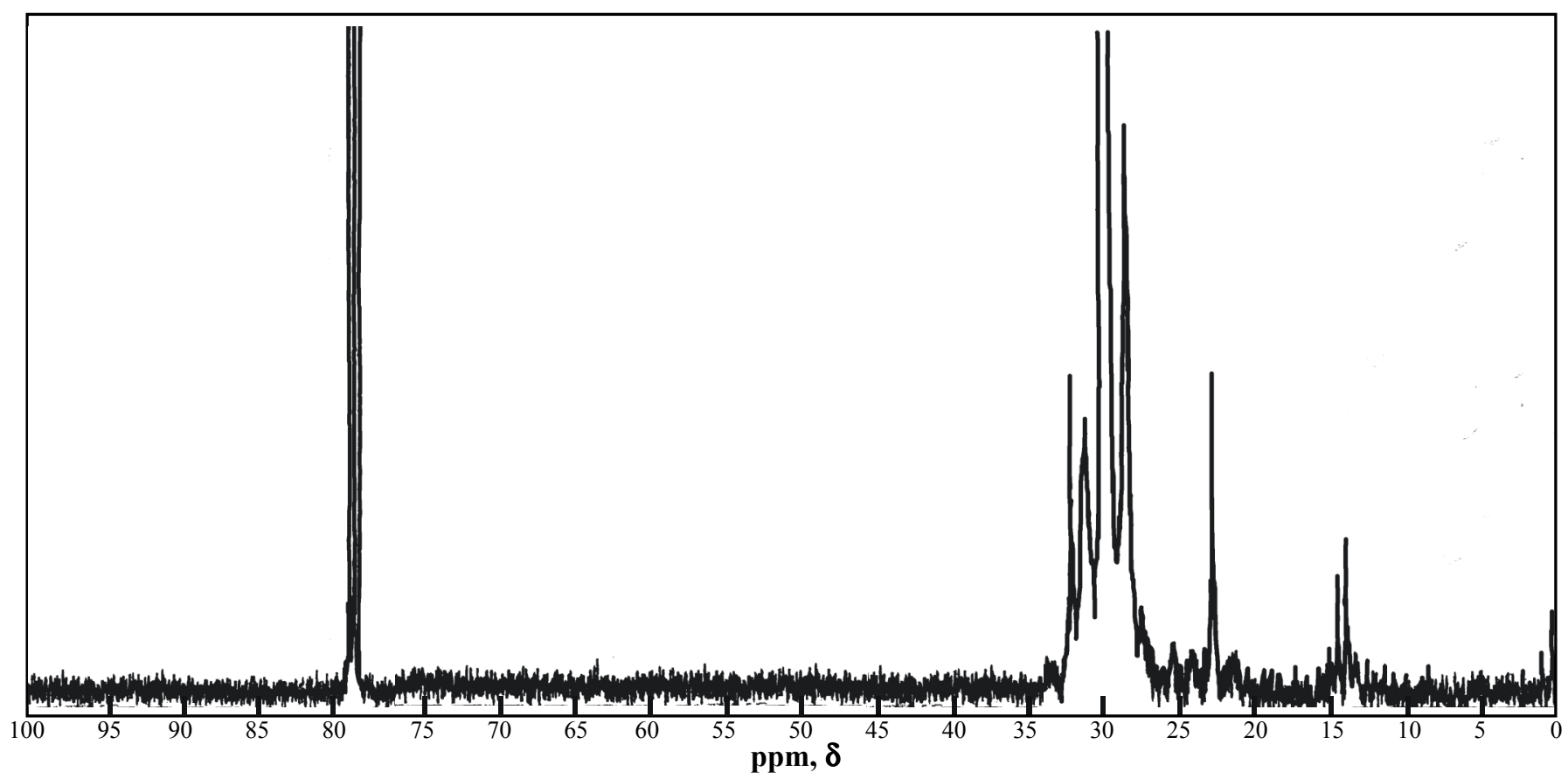

FIG. 3 - ${ }^{13}$ Carbon nuclear magnetic resonance spectrogram of the fraction purified from crude Sohxlet extract of Syzygium jambos leaves that actively stimulate germination of Puccinia psidii urediniospores. 
Hentriacontane: a leaf hydrocarbon from Syzygium jambos with stimulatory effects...

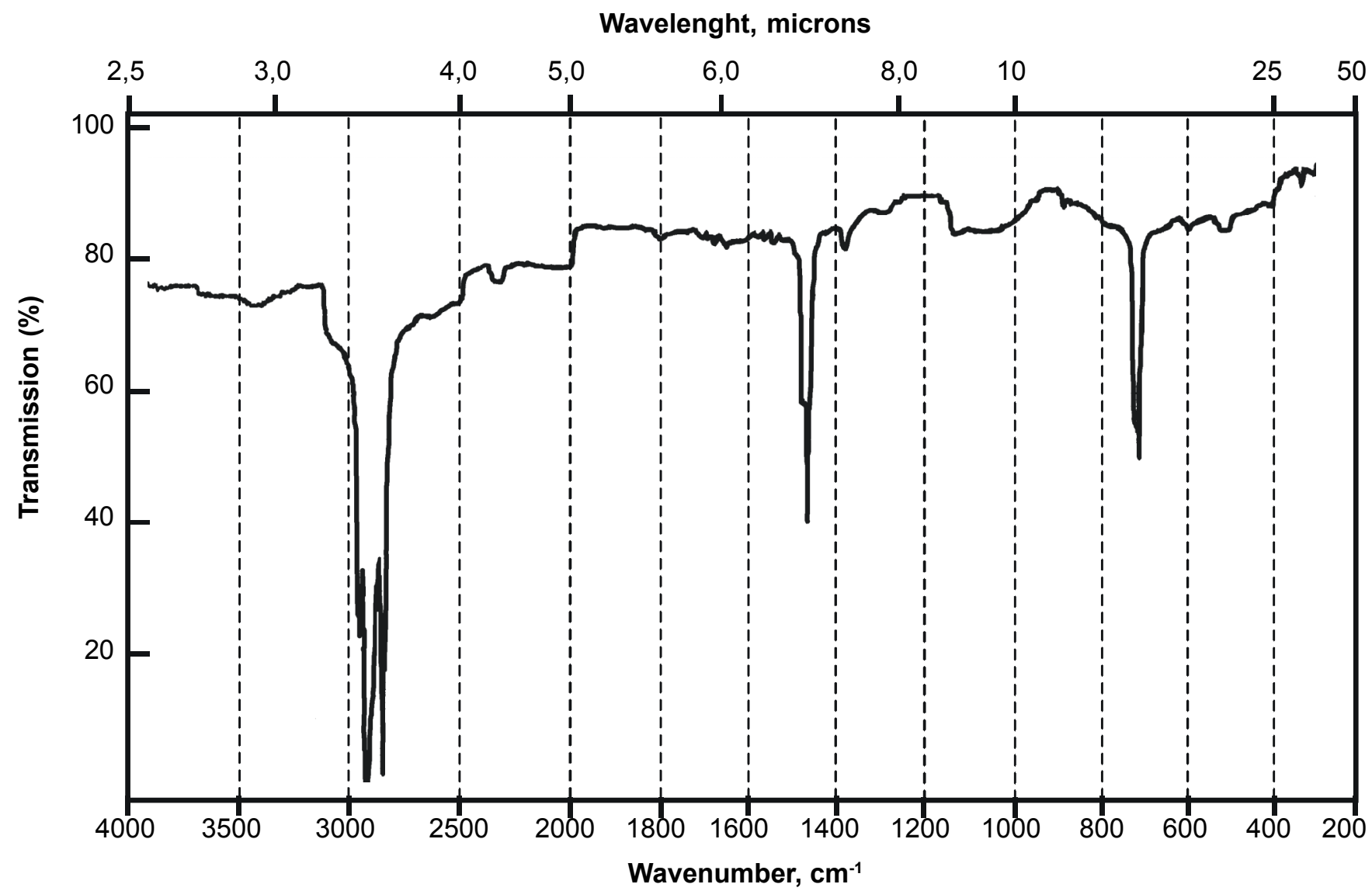

FIG. 4 - Infrared spectrum of the fraction purified from crude Sohxlet extract of Syzygium jambos leaves that actively stimulate germination of Puccinia psidii urediniospores.

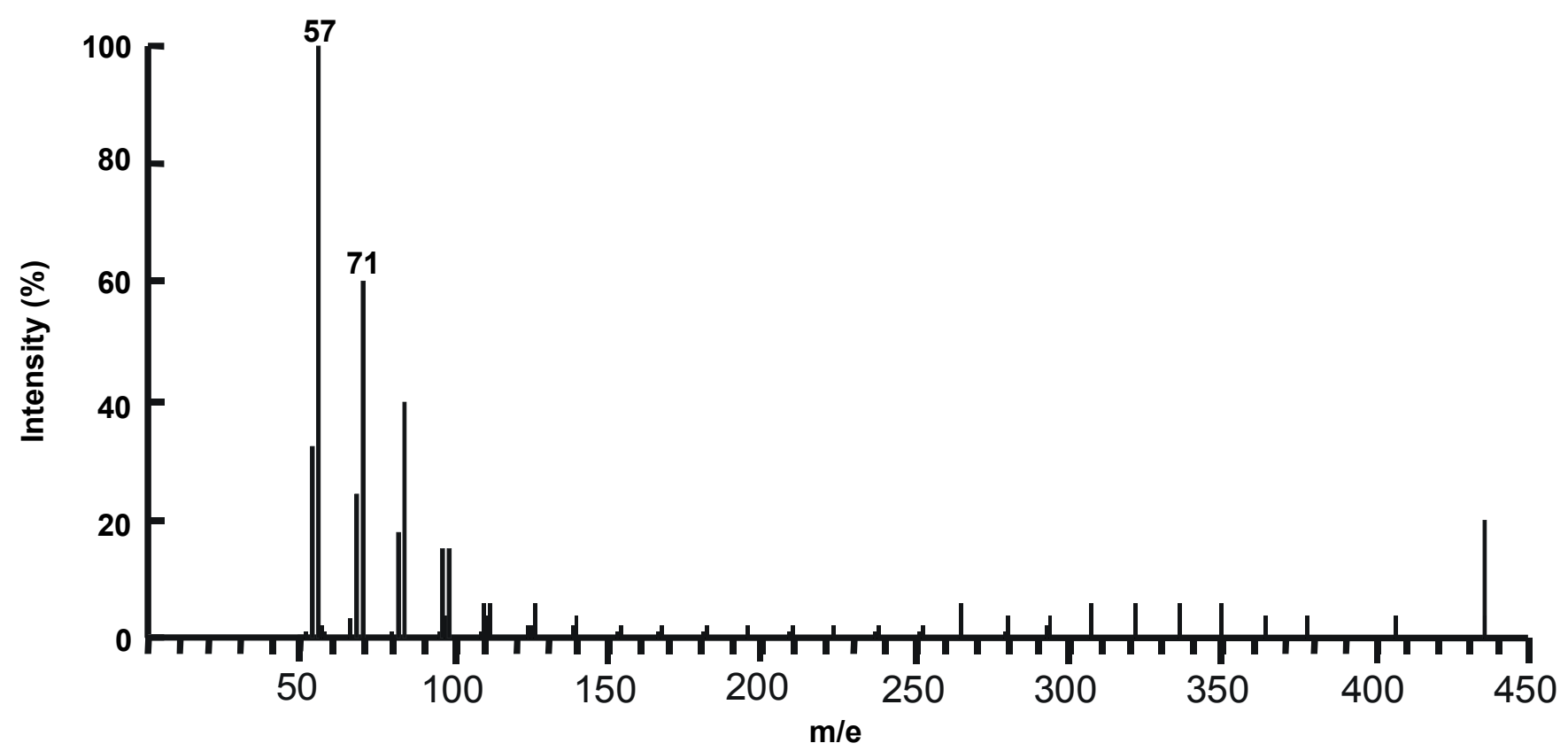

FIG. 5 - Gas chromatography-mass spectomatogram of the fraction purified from crude Sohxlet extract of Syzygium jambos leaves that actively stimulate germination of Puccinia psidii urediniospores, characterized as $\mathrm{C}_{31} \mathrm{H}_{64}$ (hentriacontane). 


\section{D.J. Tessmann \& J.C. Dianese}

hentriacontane has been recorded from epicuticular wax of several plant species (Zygadlo et al., 1994; Wang et al., 1999), this was the first evidence of its presence in plants belonging in the Myrtaceae. However, other hydrocarbons also may be present, and their role in infection by rust fungi needs to be further studied.

Now it is very important to characterize the self inhibitor present in urediniospores of $P$. psidii which does not allow in vitro germination in water while high levels of germination occur when spores are placed on host surfaces (unpublished data). Finally, it must be emphasized that the use of mineral oil as surfactant in inoculations to test fungal pathogenicity or virulence (Lehman \& Shaner, 1997; Pretorious et al., 1999) may produce unrealistic results since it might be, by itself, performing as a stimulant of urediniospore germination.

\section{ACKNOWLEDGEMENTS}

The authors thank CNPq (Brazilian National Council for Scientific and Technological Development) for a grant to the second author, which partially supported this study, and also for a fellowship for the senior author.

\section{LITERATURE CITED}

CHARUDATTAN, R., MCKINNEY, D.E. \& HEPTING, K. Production, storage, germination, and infectivity of uredospores of Uredo eichhoniae and Uromyces pontederiae. Phytopathology 71:1203-1207. 1981.

COUTINHO T.A., WINGFIELD, M.J., ALFENAS A.C. \& CROUS, P.W. Eucalyptus rust: a disease with the potential for serious international implications. Plant Disease 82:819-825. 1998.

DIANESE J.C., MORAES T.S. DE A. \& SILVA A.S. Response of Eucalyptus species to field infection by Puccinia psidii. Plant Disease 68:314-316. 1984.

FERREIRA F.A. Patologia Florestal - Principais Doenças Florestais do Brasil. Viçosa. Sociedade de Investigações Florestais/ Universidade Federal de Viçosa. 1989.
FRENCH, R.C. Volatile chemical germination stimulators of rust and other fungal spores. Mycologia 84:277-288. 1992.

FRENCH, R.C. \& GALLIMORE, M.D. Effect of some nonyl derivatives and related compounds on germination of uredospores. Journal of Agriculture and Food Chemistry 19: 912-915. 1971.

GRIFFIN, D.H. Fungal Physiology. 2nd ed. New York. Wiley-Liss. 1994.

KOLATTUKUDY, P.E., ROGERS, L.M., LI, D., HWANG, C.S. \& FLAISHMAN, M.A. Surface signaling in pathogenesis. Proceeding of the National Academy of Sciences 92:4080-4087. 1995.

LEHMAN, J. S. \& SHANER, G. Selection of populations of Puccinia recondita f.sp. tritici for shortened latent period on a partially resistant wheat cultivar. Phytopathology 87:170-176. 1997.

LUCAS, J. \& KNIGHTS, I. Spores on leaves: endogenous and exogenous control of development. In: Pegg, G.F. \& Ayres, P.G. (Eds.) Fungal Infection of Plants. Cambridge. Cambridge University Press. 1987. pp. 45-59.

MENDES M.A.S., DA SILVA V.L., DIANESE J.C., FERREIRA M.A.S.V., SANTOS C.E.N., GOMES NETO, E., URBEN A.F. \& CASTRO, C. Fungos em Plantas no Brasil. Brasília. Empresa Brasileira de Pesquisa Agropecuária. 1998.

PRETORIOUS, Z.A., SINGH, R.P., WAGOIRE, W.W. \& PAYNE, T.S. Detection of virulence to Wheat Stem Rust resistance gene $\mathrm{Sr} 31$ in Puccinia graminis f.sp. tritici in Uganda. Plant disease D-1999-1210-01N (on line).1999.

SCOTT, K.J. \& CHAKRAVORTY, A. K. (Eds.) The Rust Fungi. London. Academic Press. 1982.

WANG, Y.F., BRAMAN, S.K., ROBACKER, C.D., LATIMER, J.G. \& ESPELIE, K.E. Composition and variability of epicuticular lipids of azaleas and their relatioships to azalea lace bug resistance. Journal of the American Society for Horticultural Science 124:239-244. 1999.

WILKINSON, R.E. \& ROBERTS, J.J. Wheat leaf rust spore germ tube utilization of epicuticular wax components. In: Quinn, P.J. \& Hardwoods, J.L. (Eds.) Plant Lipid Biochemistry, Structure and Utilization. London. Portland Press Ltd. 1990. pp. 371-373.

ZYGADLO, J.A., MAESTRI, D.M. \& GROSSO, N.R. Alkane distribution in epicuticular wax of some Solanaceae species. Biochemical Systematics and Ecology 22: 203-209. 1994. 